\title{
Urban Sustainability and Resilience: From Theory to Practice
}

\author{
Patricia Romero-Lankao ${ }^{1, *}$, Daniel M. Gnatz ${ }^{2}$, Olga Wilhelmi ${ }^{1}$ and Mary Hayden ${ }^{1}$ \\ 1 National Center for Atmospheric Research, P.O. Box 3000, Boulder, CO 80307-3000, USA; \\ olgaw@ucar.edu (O.W.); mhayden@ucar.edu (M.H.) \\ 2 MnS Institute for Sustainable Urban Transformations, P.O. Box 21292, Boulder, CO 80308, USA; \\ gnatz@isut.org \\ * Correspondence: prlankao@ucar.edu; Tel.: +1-303-497-8104
}

Academic Editor: Tan Yigitcanlar

Received: 22 August 2016; Accepted: 16 November 2016; Published: 25 November 2016

\begin{abstract}
Urbanization and urban areas are profoundly altering the relationship between society and the environment, and affecting cities' sustainability and resilience in complex ways at alarming rates. Over the last decades, sustainability and resilience have become key concepts aimed at understanding existing urban dynamics and responding to the challenges of creating livable urban futures. Sustainability and resilience have also moved and are now core analytic and normative concepts for many scholars, transnational networks and urban communities of practice. Yet, even with this elevated scholarly attention, strategies for bridging between research and practice remain elusive, and efforts to understand and affect change towards more sustainable and resilient urban centers have often fallen short. This paper seeks to synthesize, from this issue's papers and other strands of literature, the knowledge, theory and practice of urban sustainability and resilience. Specifically, we focus on what capacities urban actors draw on to create sustainability and resilience and how different definitions of these concepts intersect, complement, or contradict each other. We then examine the implications of those intersections and differences in the efforts by urban actors to enhance the capacity to change unsustainable trajectories and transform themselves, their communities, and their cities toward sustainable and resilient relationships with the environment.
\end{abstract}

Keywords: urban; sustainability; resilience; capacity; transformation

\section{Introduction}

Urbanization and urban areas belong to a set of worldwide, multiscale phenomena that are profoundly altering the relationship between society and the environment, and affecting both urban and earth system sustainability and resilience in complex ways and at alarming rates. In recent decades, sustainability, resilience and transformation have become key concepts aimed at understanding and responding to an array of looming challenges posed by urbanization and environmental change. Yet, even though definitions and approaches to these concepts are ever-changing and highly contested, they revolve around common themes and ask large and compelling questions, such as these: How, with our growing world population, can we thrive (or even survive) on a warming planet with its degrading ecosystems? What kind of urban (or rural) lives do we want, and what kind of world could provide for those lives into the future? Furthermore, of critical importance to moving sustainability and resilience into practice, what capacities do we need to foster that will enable us to survive, or to transform our ways of living and thrive, both on and with our increasingly warm planet? [1,2]

As compelling metaphors that convey the interactions and dependencies between urban areas and the ecosystems on which they depend, the evolving concepts of urban sustainability and resilience are associated with an expansion of research around sustainability and resilience science $[3,4]$, and with 
national and transnational initiatives such as Local Agenda 21, 100 Resilient Cities and the Habitat III New Urban Agenda, which attempt to move this science into the policy action arena. Through these initiatives, urban actors seek to develop strategies for environmental protection, economic prosperity, inclusivity, and community well-being, while increasing their cities' resilience to both chronic and acute physical, social, and economic challenges [5,6].

While such work has greatly influenced officials and actors in city-regions to pursue diverse projects and actions to understand and manage their own sustainability and resilience challenges [7], consistent definitions of sustainability and resilience have remained elusive, because existing concepts are subject to widely differing framing and interpretations. Furthermore, there has been little research focusing on how different interpretations of these concepts intersect, complement, or contradict each other. Nor are the implications of those intersections and differences known. It is clear that this uncertainty of terms must also affect actions seeking to enhance the capacity of urbanites, as questions of capacity devolve to the question of capacity for what? In order to know what capacities urban actors must draw on to create sustainability and resilience, or to measure this capacity, it is most important to know what these terms mean, or what they can mean, in an operational context. Yet, however elusive the terms, in order to move out of existing trajectories of environmental degradation and risk, urban actors will need to transform themselves, their urban communities, and their cities' relationships with the environment in purposeful, and conscious ways.

Similar to such social problems as justice, urban sustainability and resilience, far from being resolved issues, are procedural and shifting concepts, that are repeatedly framed, resolved, and contested anew. Within these shifting conceptualizations, cultural values, economic, and political considerations play key roles in defining sustainability and resilience goals, thresholds, and outcomes $[1,8-10]$. In order to shed light on how these shifting interpretations intersect, complement or contradict each other, we begin by briefly describing some of the theoretical threads underlying the practice of urban sustainability and resilience. Afterward, we will explore what these intersections and contradictions imply for research, and for practices [11] aimed at improving human and ecological wellbeing and fostering capacity to respond to disruptions and hazards in cities and urban regions.

\section{Urban, Sustainability, and Resilience in Theory}

While dozens of definitions of urban, sustainability, and resilience exist, many of these definitions are context specific and contested. Here, we focus only on agreements and differences relevant to the purpose of both this paper and Special Issue.

\subsection{What Does It Mean to Be Urban?}

Notwithstanding the growing recognition of the importance of urban areas in local and global sustainability, little agreement exists among scholars and communities of practice about the definition of urban and what makes a population or place urban [12-14]. Some scholars define cities as a specific form of human association that can be characterized based upon criteria of population size, built-environment form, and economic function [15]. Three distinct indicators of urbanity result from this definition. The first is concerned with the number of people within a defined politico-administrative boundary, such as municipalities and state territories [16]. The second is physical or morphological, given by the extent and layout of the built environment, infrastructure, and land uses of a city [17]. The third is concerned with urban function, defined by economic, mobility, informational and operational connections between urban cores and outside areas [18]. Others understand cities as growth machines serving elite interests, inducing social inequality, and damaging the environment [19]. Yet for others, cities are socio-ecological systems (SES) either of interacting biophysical and socioeconomic components, or social and technical components (Pincetl and Chester, this issue). With full acknowledgement of the validity of competing definitions, 
we follow this last one, because we believe it holds the potential to integrate many different scientific understandings and approaches and to bridge some of the gaps between theory and practice.

Within the SES, dynamic interactions between human endeavor and ecosystem function have many consequences for sustainability and resilience. Here, cities become the analytical unit for research [20], as they affect the level of environmental pressure urban populations exert on ecosystems and their natural resource base [21]. Within the context of their SES interactions, cities also shape the vulnerability and capacity of their own populations to heat waves and other hazards climate change is expected to aggravate (Pincetl and Chester, this issue). Yet, while the SES concept is useful to an understanding of urban impacts and environmental feedback, it may be a too high abstraction to yield an operational understanding of lower level system interactions. Therefore, we suggest a definition of urban areas as socio-ecological systems [22,23], representing five (SETEG) domains [5,24]: Socio-demographics, Economy, Technology, Environment, and Governance, which we will characterize in this section (see also Table 1).

Table 1. Framings of SETEG domains: a comparison.

\begin{tabular}{|c|c|c|c|}
\hline $\begin{array}{c}\text { Approach to } \\
\text { SETEG Domain }\end{array}$ & $\begin{array}{c}\text { Dominant Development } \\
\text { Paradigm }\end{array}$ & $\begin{array}{c}\text { Thin to Thick Versions of } \\
\text { Sustainability }\end{array}$ & $\begin{array}{c}\text { From Fail-Safe to } \\
\text { Safe-to-Fail Resilience }\end{array}$ \\
\hline Socio-demographics & $\begin{array}{l}\text { Unlimited population growth; } \\
\text { Equity left to market }\end{array}$ & $\begin{array}{c}\text { From less to more emphasis on } \\
\text { limiting population growth \& } \\
\text { addressing inequality }\end{array}$ & $\begin{array}{l}\text { Lower to higher emphasis on } \\
\text { equity in distribution of } \\
\text { benefits and risks }\end{array}$ \\
\hline Economy & Unlimited growth & $\begin{array}{l}\text { From per unit to total } \\
\text { reductions in resource use and } \\
\text { pollution }\end{array}$ & $\begin{array}{c}\text { From emphasis in efficiency } \\
\text { and predictability to flexibility } \\
\text { and redundancy }\end{array}$ \\
\hline Technology & $\begin{array}{l}\text { Limitless potential for } \\
\text { technology to support or replace } \\
\text { resource consumption }\end{array}$ & $\begin{array}{l}\text { From lower to higher } \\
\text { emphasis on the intrinsic } \\
\text { values of nature }\end{array}$ & $\begin{array}{c}\text { From hard armoring to softer, } \\
\text { flexible systems }\end{array}$ \\
\hline Environment & $\begin{array}{l}\text { Source of resources and } \\
\text { pollutant sink }\end{array}$ & $\begin{array}{l}\text { Some to many intrinsic values } \\
\text { in nature }\end{array}$ & $\begin{array}{l}\text { From bounce back to } \\
\text { bounce forward }\end{array}$ \\
\hline Governance & $\begin{array}{l}\text { Decision making by elites } \\
\text { and experts }\end{array}$ & $\begin{array}{c}\text { From less to more emphasis on } \\
\text { collaborative and inclusive } \\
\text { decision making }\end{array}$ & $\begin{array}{c}\text { From lower to higher } \\
\text { emphasis on consideration of } \\
\text { and collaborations across scale. } \\
\text { From steady-state to adaptive } \\
\text { shift approaches }\end{array}$ \\
\hline
\end{tabular}

Sources: References [24,25] and Meerow and Stulz this issue.

\subsection{What Does It Mean to Be Sustainable?}

Sustainability theory has its origins in biology and ecology, where it refers to the rates at which renewable resources can be used or polluted without affecting ecosystem structure and function [26]. Some branches of economics used these principles to examine the connections between natural capital and economy, leading to the founding of ecological economics, a discipline committed to wider valuation of natural capital [27]. Ecological economics attempts to establish links between human economic systems and the natural systems that support them and, thereby, to demonstrate the costs associated with environmental degradation. When applied to urban affairs, sustainability is frequently seen as a condition in which resource use and waste production by cities remain at levels below the carrying capacity of their supporting ecosystems (and the wider supporting earth ecosystem), while ensuring a capacity for sustaining life, social practices and quality of life, deemed acceptable by current and future members of a social system such as a city [28].

In contrast to these framings of sustainability, the dominant development paradigm assumes that economic growth must be continuous for the improvement of human well-being [25]. Through market mechanisms of automatic correction, this growth will compensate the future for any parts of the Environment that are overexploited or deteriorated in the process of growing [29]. Technology is one of these mechanisms. In this paradigm, continuously emerging technologies driven by market 
mechanisms will allow for infinite substitutes to be found for resources that are being depleted today (see Table 1: Technology).

Many framings of sustainability share fundamental elements, especially visible in their opposition to the dominant paradigm [25]. In these framings, the environment is often seen in relation to economy and society. Using concepts such as the "triple bottom line", "three Es", "three legged stool", or "Venn diagrams" [30], these approaches describe relationships and interdependencies among the economy, the environment, and social equity. The assumption is that each leg is equally important, and none should be taken for granted. Social equity is viewed as intergenerational, and sustainability timescales are longer-term or indefinite, with the idea that future generations must be considered by our current actions [31]. Thus, concepts of sustainably attempt to grapple, not only with timescales that are vastly expanded but also place more value on collaborative and inclusive decision-making compared to those considered in conventional business and governance models (Table 1: governance). This difference in scale creates an obvious conflict with the dominant paradigm, a point we will return to later.

Approaches to sustainability have been viewed as ranging from "thin" to "thick", depending on where they fall on a line between polar opposite viewpoints (e.g., the dominant paradigm vs. deep ecology; Table 1: environment) [25]. In this opposition, while the dominant paradigm sees the environment as a source of raw materials and a sink for pollutants from human economic activity, deep ecologists call for acknowledging the intrinsic values in nature, as of a higher order than human economic value, and leaving them untouched [32]. In between these opposites, many definitions of sustainability attempt to balance tradeoffs between parts of the environment deserving protection in their own right, and the societal costs and benefits of these decisions. The desirability of economic growth is highly contested in existing sustainability framings, with thin approaches focusing on per unit reductions in resource use and pollution (also called relative de-coupling [33]). For their part, thick versions look for reductions in aggregate consumption, through decreases in growth rates, the size of the economy, or by improving the options for people to pursue their lives without increases in consumption [34] (Table 1: economy). Technology is another controversial element in sustainability framings. While the dominant "technocratic paradigm" [35] tends to perceive technology as key to solving sustainability challenges [36], and some thin definitions of sustainability tend to adopt this view, thicker framings of sustainability tend to be deeply skeptical, ruling out "technologies with the risk of major, irreversible, negative consequences" (Table 1: technology) [25].

Within sustainability divisions, differences also exist in the importance placed on the domain of socio-demographics (Table 1: socio-demographics). For instance, thick interpretations of sustainability support steep reductions in populations over time, in order for the economy to slow down or even reverse without affecting per capita economic output. In contrast, thin versions suggest that population increases be offset through per capita reductions in resource use and emissions. When looking at social equity, thinner approaches to sustainability are often silent on redistribution of current resources across society [25], while thicker versions are more often concerned with the consequences and "rightness" of sustainability action, as captured under the rubric of environmental justice [37]. Hence, thick versions often engage with questions such as: who in the city has the right to use natural resources, deteriorate ecosystems, and emit pollutants; and who is (or should be) responsible for ameliorating impacts, and bearing or reducing environmental risks? [38]. Such environmental justice concerns also refer to fairness in the political processes that allocate resources and resolve disputes around who bears the costs and benefits of risk reduction, risk management and human security [39]. In the dominant paradigm, the connections between population, social equity and the environment are overlooked altogether and left to market dynamics, ambition, industriousness, and productivity to define [27].

Governance is our final (but not least important) domain in definitions of sustainability. Thick and thin approaches to sustainability differ in the amount of emphasis they put on governmental action to create sustainability, particularly with regard to local action (Table 1: governance). While cities are key resource users and sources of emissions, in many cases, only a small fraction of the impacts on cities are under the direct control of municipal governments [40]. Other jurisdictions and actors, 
such as national governments, the private sector, and individuals control many of the causes of city level impacts or the means of effectively responding to them. Coordinated action between these actors is rare [41]. Yet sustainability challenges are cross-scale, and urban areas are affected by actions beyond their boundaries [42]. Likewise, urban impacts, risks, and actions create effects far outside of the demarcations of their city limits. Because of its cross-scale interactions, efforts to create sustainability challenge a range of actors across sectors to create coalitions for multilevel governance; yet it is here that we encounter a paradox-of-practice, as cross-scale cooperation is often constrained by power imbalance and turf concern [43]. In order to create effective policies and actions to steer cities toward sustainability, cooperation between these levels will be necessary [43].

We define multi-level governance as the set of formal and informal rules, rule-making systems, and actor networks at all levels (from local to global) both in and outside of government [44]. An analysis of the capacity to develop governance solutions for sustainability includes these elements [41]:

(1) Different types of actions developed and implemented in urban areas

(2) Actors and networks at multiple levels

(3) The nature, opportunities, barriers, and limits that multilevel governance poses to local policy

(4) Gaps between the policy discourse and the challenges that local action needs to address under real-world conditions

\subsection{What Does It Mean to Be Resilient?}

The term resilience, which has a long history, with roots in ecology, engineering and psychology, has also been defined in different ways (see urban relevant definitions in Meerow and Stulz, this issue). Within mathematics, physics and engineering, it is often described as the capacity of an ecosystem to "bounce-back" or return to a steady-state equilibrium (Table 1: environment). Examples of bounce-back can be found in restoration of template forests and recovery after such stressors as floods, political turmoil or a banking crisis [45]. The emphasis of this "fail-safe" engineering or steady-state approach, is on return time, "efficiency, constancy and predictability of economic use of natural resources and ecosystem services" [46]. Conversely, in definitions rooted in ecology, resilience is often viewed as a system's ability to "bounce-forward". Within an urban socio-ecological system, ecologists ask how much disturbance an ecosystem can absorb or adapt to and remain within critical thresholds before it moves to another regime. In this "safe-to-fail" perspective [47], which challenges the notion of steady-state equilibrium, resilience is not conceived as a return to normality, but rather as the ability of complex ecosystems or socio-ecological systems, such as cities and urban communities to change, adapt, and crucially, to transform in response to both internal and external stresses and pressures [48].

Some social scientists have suggested that resilience cannot be uncritically applied to social domains [28,49]. In this view, urban groups and communities have the capacity to cope, or adapt to stresses and disruptions, but these capabilities are also shaped by social, political and cultural processes. Unpacking the SES to examine interactions between SETEG domains, can help address this concern.

Vulnerability of urban populations and cities, a related concept, is often defined as the propensity to be adversely affected [50]. For some scholars, vulnerability and resilience are inversely related [51], with their purest states appearing as extreme ends of an analytical continuum defined by exposure, sensitivity and capacity to cope with or successfully respond to stressors and hazards [20]. For others, resilience relates to the capacity component of vulnerability. Resilience applies to the ability of an urban system to stay within its "basin of attraction" [20], through an ability to cope with, or adapt to impacts and take advantage of opportunities. Conversely, vulnerability refers to a susceptibility to impacts, some of which can lead to transformations that necessarily take that urban area outside that "basin of attraction". For urban areas, a basin of attraction may be related to governance structures, infrastructures, technologies, economics, culture, tradition, habit, and political system. This list could 
certainly be expanded, but most importantly, it refers to all those things in the human realm that create inertias to change, lock-in, and path dependency.

The notion of capacity is key to connecting research providing the analytic tools and insights on existing conditions (is), in order to make the normative dimensions (ought) of urban sustainability and resilience operational and provide the means to design and implement actions towards achieving urban sustainability and resilience goals. Capacity relates to the unequally distributed pool of resources, assets, and options governmental, private, and nongovernmental actors can draw on to manage environmental risks, while pursuing the lives and development goals they value [52,53]. It makes explicit the connection to the underlying sociodemographic, economic, technological, ecological, and governance (SETEG) domain contexts that give rise to those resources. It also relates to normative and ethical principles, such as resource distribution equity. As such, it is concerned with the distribution of adaptive or transformative resources to individuals, populations, communities, and organizations. This distribution allows urban actors to envision, contest, and negotiate the urban worlds they desire to live in. Conversely, it forces some urban actors to accept that they can neither know nor achieve the means of transformation $([28,54]$ and Ziervogel, this issue). Transformation is a concept deeply embedded in human psyche and can be found across human narrative from poetic-fictive to empirical-scientific modes. It conveys the notion of systemic, essential, and radical change that has been described within and across the SETEG domains, affecting technology, ecology, socio-demographics and governance regimes $[22,55,56]$ as well as livelihoods (see Feola [57] for a review).

\subsection{What Are Urban Sustainability and Resilience?}

Interestingly, notwithstanding differences within and across approaches to sustainability and resilience, efforts have been made to integrate them. For instance, sustainable livelihood scholars and practitioners see livelihoods as capabilities and assets to pursue a living [58,59]. Within the sustainable livelihoods framework, sustainability is not only seen as a household's capability to maintain a resource base (natural and social) but also to respond to stresses and shocks. SES scholars have also analyzed the dynamic economic, equity and environmental dimensions of resource use and vulnerability or resilience in the face of stresses and disturbances cities constantly encounter. In this spirit, a key goal of this paper and Special Issue is to connect and unpack the existing and potential capacities to pursue urban sustainability and resilience. Toward that end, we will now briefly describe some of the most influential movements and interpretations of these concepts.

By coalescing concerns in research and policy for the betterment of human with ecosystem conditions, the Brundlandt commission [60] helped spark the development of a series of city relevant sustainability frameworks. For example, economic models based on rational theories of decision making [61] and steady-state interpretations of temporal scales, use a timescale and discount rate to analyze sustainability as the efficiency of the rate at which an individual values the future. Therefore, the discount rate seems to give low values to future damages, and thus, to "play against" the environment and future generations [62]. For ecologists interested in the relationships between urban ecosystems and the environment, sustainability is a condition in which urban populations' needs are met without excessively or irreversibly drawing down the carrying capacity of their hinterlands and the regions they depend on regionally, nationally and globally [26]. An influential idea emanating from a combination of the ecological and economic approaches, the ecological footprint [63], sheds light on both carrying capacity and inequalities in resource consumption by calculating the amount of biologically productive land area that would be needed to maintain the flows of natural resources and wastes needed to maintain the production and consumption activities of consumers, companies and districts in a city. In the "triple bottom line" or "three E" approach, including economic, environmental and equity dimensions of development, the ideal urban sustainable community will become green, profitable and fair, all at the same time [64]. Many suggest that the three elements can be combined through strategies and planning instruments such as eco-efficiency, fair trade and substantial coalition building efforts [7]. This can help make sure that advancement in one goal, such as land or energy 
development does not come at the expense of others, such as affordable housing, human health and climate change mitigation. However, efforts to negotiate and balance the three pillars ought also to acknowledge the political imbalance between the three [64].

Resilience seems to be increasingly embedded in the everyday discourse of scientists and urban communities of practice (e.g., eight out of 11 papers in this issue are devoted to it). Two analytical concepts underpin bounce-forward interpretations of resilience: adaptive cycle and panarchy [65]. The adaptive cycle graphically represents the dynamics of socio-ecological systems through four phases (Figure 1): Together, these phases comprise a cycle that begins and ends in the reorganization, Alpha $(\alpha)$ phase, with the system in a state of high potential and availability of resources for exploitation, opportunity, innovation, and exploitation. In Alpha $(\alpha)$, opportunities begin to be taken up by pioneers (species/companies/social movements) and the first internal dynamics and interactions of the system take shape. As these interactions and dynamics accelerate and forces are mobilized, the system moves into an exploitation-growth phase (r). The exploitation phase begins to slow as winners and losers appear, niches, and carrying capacity limits (natural) or laws and rules (social) arise reinforcing connections and patterns of social exclusion, polarization and forces of stabilization bring a shift into the conservation-institutionalization $(\mathrm{K})$ phase. The tightly bound exigencies of the $\mathrm{K}$ phase also create a form of destructive potential, like a wound spring, and eventually give way to their own internal contradictions, conflicts or pressures for release, scatter, or collapse, Omega $(\Omega)$. This release reopens opportunities for transformation and reorganization or renewal to begin again in the Alpha phase [65]. Capacity entails two main transitions or phases: the fore loop, from $\mathrm{r}$ to $\mathrm{K}$, is the incremental phase of growth and accumulation; and the back loop, from Omega to Alpha, is the rapid phase of reorganization leading to renewal. The concept of panarchy conveys the idea of a dynamic and evolutionary interaction between nested, socio-ecological systems, interacting across scales, between larger, slow moving, and smaller, fast moving systems $[45,66,67]$. Socio-ecological systems such as cities operate at various scales of space, time, and social organization. Panarchy helps to explore how the interactions across scales shape the dynamics of a city at any specific scale [68], a point we will come to in the next section.

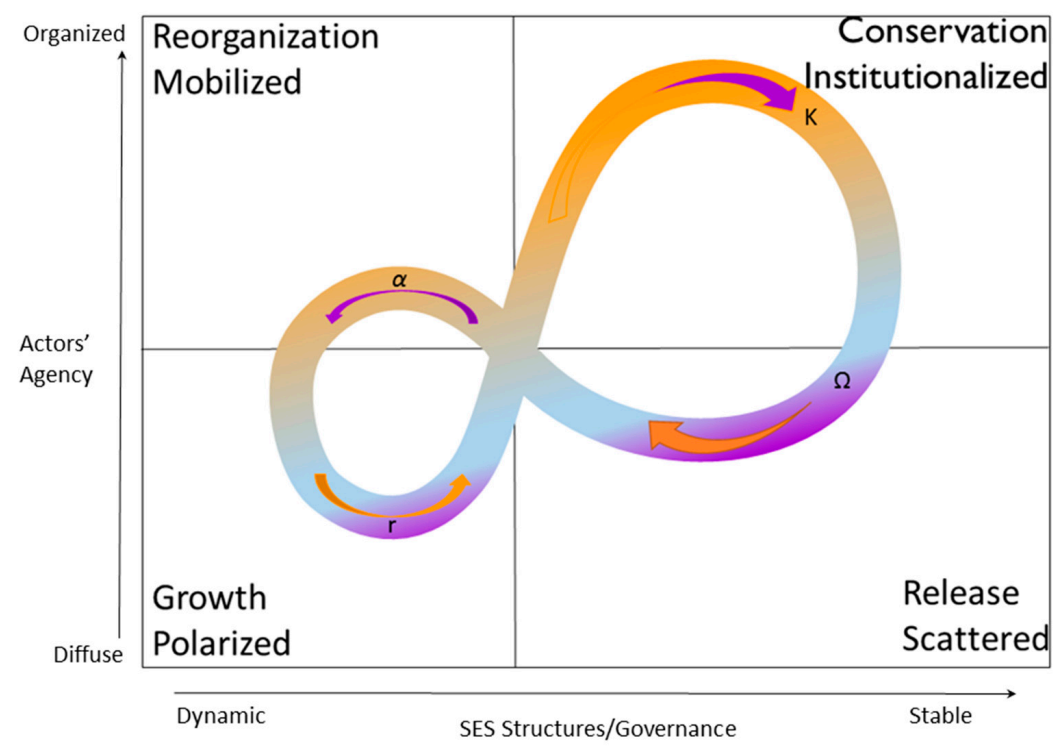

Figure 1. Application of the adaptive cycle to urban socioecological systems; Source: based on Pelling and Navarrete [69]; Graphic design by Karen Griggs.

\subsection{Applicability and Critiques}

The applicability of resilience and capacity to urban affairs has been creatively and, sometimes, critically embraced by social scientists [69]. Some have combined it with an analysis of structures 
of legitimation, domination and signification to examine how power is held and used to promote or maintain certain pathways of urban development, and how transformation is blocked or may be facilitated in select cities [2]. Others have connected it to the interpretive approach to urban planning and its emphasis on fluidity, reflexivity, contingency, connectivity, and multiplicity [46]. Yet others, within the disaster risk field, have defined resilience of communities. In these definitions, communities have shared fate and geographic boundaries, and are the product of a complex interaction of "built, natural, social, and economic environments" [70]. Each community has a dynamic set of capacities (resources, assets and options) to respond to disruptions, hazards or adversities [70]. These capacities, which are also key for sustainable livelihoods, manifest in a population's wellbeing after a disturbance, as evidenced by high and non-disparate levels of health, functioning, and quality of life within a community. Ziervogel et al. (this issue) suggest that capacity can be nurtured through a focus on three transformative attributes: mindfulness and re-connection to natural (water, food, energy, and air) and human-made elements (governance, infrastructures, and economic) supporting people's wellbeing; sense of agency, in both individuals and groups; and strong social and community cohesion.

Notwithstanding that many conceptualizations of sustainability and resilience have gained broad acceptance, some have also been subject to critiques. For instance, in sustainability theory, economic models of rational decision making around intertemporal rates of resource use and waste emission tend to oversimplify the issue and omit consideration of shifts between multiple possible equilibria states, irreversibility, and the challenges of decision making, under conditions of uncertainty, by groups of actors with different values, stakes and power levels [71]. Far from achieving a balance between the three pillars of the triple bottom line approach to sustainability, urban governmental, private, and nongovernmental actors encounter tension between three often incongruent and politically unbalanced priorities, with equity and environmental issues taking the back seat to growth and development $[30,72]$. Scholarship has overwhelmingly shown how pro-growth coalitions and middle class interests frequently outmaneuver concerns for the poor, the vulnerable, and the environment in cities worldwide [39,41]. In many cases (see Fernandez et al., this issue), inequality becomes a long-lasting legacy, springing from disproportionate private sector influence within urban development planning circles.

Concerns have also been raised around socio-ecological approaches to both concepts $[2,28,46]$, which have often been criticized for determinism and omission of the role of different levels of agency and power in creating or preventing transformational movement away from previous system phases and cycles. These scholars call for iterative and inclusive approaches to governance (Table 1: governance). As illustrated by Fernandez et al. (this issue), pro-growth coalitions, unabated by powerless local authorities and civil society organizations, pose challenges to navigating towards more sustainable development. Conventional socio-ecological approaches often minimize the importance of individual and collective potential for inventiveness, technology, vision and power in moving the system to different, and not necessarily desirable states. Within the technological domain, resilience paradigms can range between concepts of hard armoring (resulting in greater path dependency) to stop the onslaught of nature to softer systems that can shift to different states dependent on conditions (Table 1: technology).

Conventional SES approaches to sustainability and resilience omit key questions around social and spatial equity by failing to ask for whom, when, and where sustainability and resilience will be promoted. Whether resilient or not, urban development, while desirable for elites within a city, is often highly undesirable for other urban populations bearing the brunt of the stress and hardship associated with urban transformations (Fernandez et al., this issue). Furthermore, governmental and nongovernmental actors can purposefully act (e.g., build dikes or import water from external basins) and by so doing decrease, sustain, or enhance the sustainability and resilience of a city over a relatively short-term. These actions can create an appearance of sustainability or resilience by postponing the effects, in space and time, of energy and water use, waste generation, and social and environmental disruptions and stressors. However, the long-term results of such actions may create impacts to the 
urban system over larger spatial and temporal scales and ultimately undermine their own resilience and sustainability within the larger earth systems they impact (Aldunce et al., this issue). Of course, the logic behind such environmental impact delaying actions is that, with more time, better solutions might be found in the future that will move the system back to sustainability or resilience. However, the resulting larger systemic issues will also need to be dealt with by future generations.

From the above discussion, we can conclude that it is fundamental not only to approach urban sustainability and resilience as scientific dilemmas but also as social and ethical issues. Concepts of sustainability and resilience resonate with different ways of knowing, values, motivations, and power dynamics across spatial and temporal domains. Therefore, they are bridging concepts ([46] and Aldunce et al., this issue) that demand collaborative knowledge production between researchers, decision makers, and communities [73,74]. To find larger integrations of these concepts, it will be necessary to elicit differences and commonalities of meaning and scope between these stakeholders; to agree on what dimensions and attributes to include in analyses; and to address the social and spatial equity questions of for whom, what, when and where we want to promote sustainability and resilience. Of course, these questions open up the looming issue of power dynamics in the decision making process and how these play out to create action. In the next section we will synthesize existing approaches to addressing these questions and lay out critical knowledge pathways to navigate this labyrinth.

\section{Research Efforts to Study Urban Sustainability and Resilience in Practice}

There are many different approaches and recommendations in the theoretical and practical literature on the analytic ("is") and normative ("ought") dimensions of urban sustainability and resilience. Therefore, rather than suggesting yet another framework, in this section we sketch a roadmap synthesizing fundamental components and questions defining existing, and potential, research on urban sustainability and resilience that can productively guide future research and practice.

\subsection{Causal Relationships and Attributes}

Diverse quantitative and qualitative methods have been devised to analyze a myriad of social, economic, technological, ecological, and governance processes of urban development. Yet these studies have not attempted to examine interactions between the SETEG domains comprehensively. Furthermore, examinations of these processes usually fall to explaining deficiencies in sustainability or resilience and to defining what combinations attributes accurately characterize these deficiencies in units of analysis ranging from segments of urban populations to whole cities, urban regions and countries (see Shen et al., and Suarez et al., this issue).

For example, socio-ecological systems approaches to urban sustainability focus on the dimensions and attributes explaining the long-term impacts cities have on their resource bases, ecosystem functions, and populations' welfare. They apply indicators of (a) sources of energy, water and other natural resources; (b) sinks affecting such things such as the quality of water bodies, air pollution levels and GHG emissions, based on the ability of natural systems to absorb urban wastes and byproducts, within limits set by carrying capacity; (c) dynamics of ecological support systems, e.g., climate regulation, flood protection; (d) socio-demographic characteristics of urban communities, infrastructure, and aspects of the economy affecting sustainability and resilience; and (e) impacts on human welfare [26].

Scholars researching urban sustainability and resilience, as processes determined by a context specific combination (or lack) of capacities, focus on (dynamic) attributes of resources, assets and options urbanites draw upon to respond to disruptions and stresses they encounter (resilience), while pursuing their livelihoods, businesses, and urban planning and management goals (sustainability). This issue offers examples of efforts to capture the attributes defining these capacities. Romolini et al. (this issue) suggest a social-ecological framework (STEW-MAP) for examining and understanding urban stewardship networks in the cities of Baltimore, Chicago, Los Angeles, New York, San Juan, and Seattle. Their goal is to identify and examine relationships between these 
organizations and the ecological phenomena with which they interact. Building on Ostrom [23], Schauppenlehner-Kloyber et al. (this issue) identify critical attributes defining governmental and nongovernmental actors capacities to govern the sustainability and resilience of urban commons in the Austrian city of Korneuburg. Key attributes are (a) well-defined boundaries around who participates and the spatial delimitation of the urban resources; (b) congruence among benefits, risks and costs for participants; (c) actors who have the right to co-design their own rules; (d) regular monitoring of actors and resource conditions; (e) graduated sanctions to maintain cohesion; (f) mediation and conflict-resolution mechanisms; (g) minimal recognition of participants rights by government; and (h) allocation of authority for adaptive governance at multiple, nested levels.

Other scholars have identified a series of political and economic factors determining institutional capacity for change in cities $[75,76]$. Institutional capacity here refers to the broad pool of resources urban governmental, private, and nongovernmental actors can use to pursue both sustainability and resilience goals (e.g., reducing energy use or adapting to climate stresses). Scope and effectiveness of actions was found to be affected by these factors [41]:

(1) Composition of the group — as defined by the multilevel actors and networks involved, and the mechanisms in place for actor engagement and participation

(2) Legal frameworks in place to define responsibilities, decision making power, and planning mechanisms

(3) Generation and transmission of information and different ways of knowing

(4) Financial resources, decision-making power, and leadership.

Meerow and Stultz and Aldunce et al. (this issue) use a literature review and a participatory approach to identify attributes of urban resilience in theory and practice. While Aldunce et al., highlight the importance of co-production in turning abstract factors into concrete, context specific and socially relevant knowledge, Meerow and Stultz find that scholars and practitioners define urban resilience differently, with the latter using more engineering, steady-state approaches (Table 1: Governance), which run the danger of focusing urban policy action on maintaining the status quo.

A different picture emerges from analyses focused on urban sustainability and resilience at the community level. For instance, McMillen et al. (this issue) analyze the broader sustainability implications of resilience attributes, such as place attachment, social cohesion and networks, and knowledge exchange and diversification. These are attributes of stewardship practices, defined as actions of caring for the environment "to enhance the quality of life for the greater public good". Two stewardship practices, urban gardens, and the Living Memorials Project, in response to the losses due to the September 11 terrorist attacks in New York, provide a sense of place attachment and identity that can enhance urban communities' empowerment and sense of agency.

For scholars using livelihoods approaches to research sustainability and resilience of urban households, stresses and hazards interact with historic patterns of socio-economic and institutional segregation, placing some urban populations in hazard-prone areas and endowing households with access to resources and options differently [77-80]. Forces of socio-economic and socio-spatial segregation are conditioned by interactions between SETEG domains.

Without specifically naming them as such, scholars identify key SETEG factors determining populations' resilience or vulnerability (see Table 2): (1) the characteristics of the stressors or disruptions to which populations are exposed (e.g., magnitude, intensity and timing); (2) the set of multilevel capacities allowing populations to respond, and pursue their livelihoods; and (3) the responses to and impacts of the stressor(s) on populations' wellbeing (e.g., their health; patterns of behavior, and functioning at home, school, or work). Capacities are determined by historically constructed social and institutional factors [79,81]:

(1) Urban labor, land and housing markets;

(2) Legacies of past political decisions around land use planning, infrastructures and services; 
(3) Mechanisms of social exclusion (e.g., through race and gender);

(4) Actual or potential resources that are connected to possession of a durable network of social interactions;

(5) How populations perceive networks (e.g., as caring and readily available, or aloof and unavailable) as well as how they use them to pursue their life and development goals and to respond to hazards;

(6) Information and communication as access to useful information is a key resource that allows sustainable and adaptive performance [79].

Table 2. Example of Indicators of an Urban Population Resilience [79].

\begin{tabular}{ccc}
\hline SETEG Dimensions & Hazard Exposure & Sensitivity and Capacity \\
\hline Socio-demographics & $\begin{array}{c}\text { Population in hazard-prone areas, } \\
\text { Population growth rate }\end{array}$ & $\begin{array}{c}\text { Age, gender, education, ethnicity, } \\
\text { linguistic isolation, perception }\end{array}$ \\
\hline Economy & $\begin{array}{c}\text { Service, industrial, activities and utilities } \\
\text { in hazard-prone areas, land uses }\end{array}$ & $\begin{array}{c}\text { Income, unemployment, insurance, } \\
\text { home ownership }\end{array}$ \\
\hline Technology & $\begin{array}{c}\text { Housing density, location of } \\
\text { infrastructure and utilities }\end{array}$ & $\begin{array}{c}\text { Settlement type, housing design, } \\
\text { hazard mitigation infrastructures }\end{array}$ \\
\hline Ecology & $\begin{array}{c}\text { Temperature, precipitation, } \\
\text { topography, land cover }\end{array}$ & $\begin{array}{c}\text { Land use and land cover, } \\
\text { deforestation and erosion, green ways }\end{array}$ \\
\hline Governance & $\begin{array}{c}\text { Land use zoning, building codes, growth } \\
\text { cap, floodplain maps, wildfire maps }\end{array}$ & $\begin{array}{c}\text { Actor-networks, emergency response } \\
\text { systems, operating community groups }\end{array}$ \\
\hline
\end{tabular}

These last two attributes interrelate, as communication is a two-way transmission of meaningful information that creates shared meaning and a chance for community members to express needs and exchange views $[72,79]$.

\subsection{Relationships between Attributes and Outcomes}

In order to better understand the links between attributes of dimensions of urban development and sustainability and resilience, scholars and communities of practice have compared examples from local contexts to show how differences in relevant attributes may affect outcomes. A solid body of literature exists on the links between sustainability or resilience outcomes and a variety of attributes-from city size through socio-economics to multilevel governance and sustainability actions in cities (see Wu et al., this issue). This literature will be boosted by the framework for implementing Sustainable Development Goals (SDG), particularly SDG 11, which calls to "make cities and human settlements inclusive, safe, resilient and sustainable" [82], as it is mostly concerned with the extent to which local governments have and will commit to sustainability and resilience principles in their planning practices [7]. Scholars are already pointing to challenges of data availability to monitor SGD performance, in terms of issues such as indicators chosen, data sources, and level of temporal and spatial resolution [83]. In seeking to understand the low levels of adoption of sustainability policies and actions by city officials, Svara et al [84] identify a comprehensive set of explanatory factors. These factors include not only control variables (e.g., city density and population), but also forms of government, policy priorities, and community attributes such as age, income, education, home ownership and ethnicity (see also [40,72]).

A Pressure-State-Response conceptual model focuses on two main forces determining sustainability or resilience outcomes: the processes involving increasing pressure and the processes relieving that pressure [85-87]. Blakie et al., (2004) the creators of this model, point to how disasters (an outcome ) are created by pressures, such as physical or biological hazards and the cumulative progression of vulnerability resulting from historic processes of socio-spatial differentiation; and to how disasters are also mediated by dynamic pressures such as governance structures. This approach, which has been used by the Organization for Economic Co-operation and Development (OECD) to 
measure urban sustainability over more than two decades, entails indicators of three dimensions: (i) stresses or disruptions such as financial turmoil and climate change; (ii) urban conditions such as quality of access to energy and water, ecosystem services, and human health; and (iii) capacities to respond including financial and technical resources, city expenditures and actions [88].

In the current context of daunting social inequality worldwide [89], key to creating a science that can engage with and inform actions to enhance sustainability and resilience across scales, will be understanding how urban households, ranging from poor to wealthy, vary in their capacities to create sustainability and resilience and knowledge of the processes creating this variability. Some scholars have combined qualitative and quantitative methods to analyze the relative influence of wealth and inequality on differentiated capacities to respond to climate stressors, within and across household classes in cities [79]. They have found that under current climate conditions, high household vulnerability levels in cities are accounted for mainly by differences in indicators of wealth (e.g., land tenure, housing, stable income, infrastructure) and of capacity (e.g., education, reliance on community support). Urban development attributes of wealth and capacity are fundamental determinants of resilience across cities worldwide [78,90-92]. Since this pattern of unequal access to resources and options could be aggravated in a future (warmer) world, scholarship clearly points to the urgency for capacity enhancing actions and policies to increase the resilience, particularly of vulnerable populations. Furthermore, research suggests profound transformations are necessary towards policies and actions addressing the structural drivers of social marginalization and exclusion in cities ([79] and Fernandez et al., this issue).

\subsection{Comparison and Classification}

Several efforts have been made to compare and rank urban sustainability or resilience attributes, trends and actions within and across cities. The most common tool to do this is the use of indicators for an array of analytic and normative purposes: to improve scientific understandings and make comparisons; to capture multiple aspects of urban sustainability and resilience; to determine baseline conditions and measure trends; and to support decision making through monitoring and warning systems $[88,93]$. Because urban sustainability and resilience are multivariate and multifaceted, a range of different methods can be used to characterize the relative importance of indicators. For instance, some scholars and practitioners have applied the three Es approach (environment, economy, and equity) to create indicators of performance to guide actions seeking to achieve more sustainable pathways of urbanization (e.g., OECD and Shen et al. this issue). Others have grouped indicators into the three Es to capture the sustainability initiatives pursued by city officials [72,84]. In a similar vein, Suarez et al., (this issue) rank resilience across 50 Spanish cities using indicators of diversity, self-sufficiency and participation.

However, the use of indicators is often fraught with problems. In measuring urban sustainability and resilience, the choice of indicators depends on the theoretical approach used, which tends to shed light on some dimensions and omit others [94]. In building indicators, scholars and communities of practice are guided not by what they should measure but by what they can, given data constraints, or what they want, given values and interpretations, hence, inevitably leaving out some key processes and interactions involved (See Suarez et al., this issue). Scholars have pointed to the need to critically and constructively embrace the following challenges: subjectivity and uncertainty in many processes involved in the selection and aggregation of indicators; the selection of indicators may not be sufficient to describe the dynamic and complex nature of urban sustainability and resilience; the weights assigned to each indicator; and the ranking of observation units into sustainability or resilience categories $[79,93,95]$. Several procedures have been applied to address and embrace subjectivity and uncertainty. These often involve developing different methods of collaboration among researchers, stakeholders, and urban communities throughout the index construction process (e.g., the selection and weighting of indicators and the aggregation of indicators) [59,96-99]. 


\section{Transitioning to Urban Sustainability and Resilience: Agreements and Differences}

While the environmental limits to development and urbanization are increasingly acknowledged internationally, nationally and locally, there is little agreement on how to transition to urban sustainability and resilience in practice, let alone how to move from incrementalism to transformation. For some, urban sustainability and resilience are technical problems that can be addressed through greater knowledge, innovation and technical expertise. Others (including us) see these challenges as opportunities to engage in co-production, to explore and address the underlying urban development drivers and causes of environmental change $[2,100]$ (e.g., Ziervogel et al. this issue). Moreover, we need an understanding of the social, economic, technological, environmental, and governance strategies and innovations needed to support efforts to navigate to sustainable and resilient futures. However, we also must acknowledge that the meanings and implications of sustainability and resilience are contested and ultimately emerge from deliberations among actors with unequal levels of power about the desirability of alternate futures, the necessary means of attaining them, and the tradeoffs that will be accepted along the way. As such, sustainability and resilience require innovative approaches to understanding the social dimensions of change [11] and engaging science with society at large [101].

Indeed, an increasing number of works within the literature acknowledge that the challenges of sustainability and resilience exceed the capability of traditional sustainability and resilience science and practice [100]. Furthermore, both scholars and communities of practice agree on the need for iterative approaches to science co-production (see Aldunce et al.; Ziervogel et al.; and Schauppenlehner-Kloyber et al., this issue). However, deep differences remain along two main fronts. First, those framings that suggest the use of interdisciplinary methods and data to objectively examine or co-analyze the dynamic interactions and feedbacks between social and ecological domains, in order to identify the key dynamics of urban sustainability and resilience challenges [101,102]. Second, those approaches that embrace the importance of social practices, subjectivity, values, and consciousness in defining, contesting, imagining and creating more sustainable urban worlds ([102-104] and Ziervogel this issue). In this context, rather than resulting from actions derived from scientific or expert knowledge, urban sustainability and resilience can and need to emerge from dialogues about desirable urban futures, of which the science of interactions between social and ecological systems will play a necessary but not sufficient part. As such, these goals must be informed by an understanding of the social, economic, technological, and ecological constraints to change and of the implications of different courses of action [101].

\section{Concluding Remarks}

Many papers in this Special Issue and the broader literature reviewed in this article, are driven by the conviction that climate change and other environmental challenges facing humanity not only offer reasons for concern, but also open many opportunities for contemplating, questioning, and changing our current unsustainable relationships with the environment, and with each other. Furthermore, they open opportunities to transform the ways we think about and relate to our increasingly urban world.

Some similar challenges of scope and scale exist among sustainability scholars. For instance, they tend to view the environment, through a frame of human wellbeing, with first concern for economy and society. Similarly, resilience tends to be related to a system's capacity to adapt to stresses and disruptions, often with a lower level of priority for the viability of other interacting systems. While seeing cities as socio-ecological systems can certainly extend the scope of our understanding of urban sustainability and resilience, its analyses can become too broad and may lose relevance in studying (or addressing) on the ground realities. We suggest, therefore, that the definition of urban areas as socio-ecological systems be decomposed to five SETEG domains. These domains represent subsystems of the socio-ecological universe, whose interactions can be more easily understood. We have given some examples of how indicators can be used to assess the SETEG dimensions and interactions creating urban sustainability and resilience, and discussed some of the limitations of existing approaches to indicator selection and aggregation. 
Currently, rather than gaining a profound transformation in the way we see the world, science and practice are caught between two incongruent views of urban sustainability and resilience. From one perspective, this world is mechanistic, linear, and deterministic, thus allowing for steady-state and bounce-back interpretations of sustainability and resilience. This view is very common among city officials, as might be expected based on their need to operationalize and show concrete results in time and space (and economics). This bias has been shown by Meerow and Stultz (this issue). In the opposing view, however, our urban world is dynamic, complex, adaptive, and multifaceted. A recognition of this complexity, however, must also include a recognition of sustainability and resilience as emergent and contested concepts that are continually reframed. In practice, this reframing sometimes follows the need to respond to operational realities, real or imagined.

While the concept of capacity is fundamental to linking the analytic with the normative dimensions of urban sustainability and resilience (the "is" with the "ought"), the distribution of capacity cannot be separated from the political and economic realms in which it operates. In this distribution, the resources and remit, with some urban actors having to maintain the status quo, are central to enduring (resilient) patterns of socio-spatial inequality (Fernandez et al., this issue). However, this type of resilience may ultimately be self-defeating (mal-adaptive). Yet, even within the context of social barriers, change does happen. Others have capabilities to promote and innovatively nurture the transform the potential of communities (e.g., the youth) to reconnect to "life-support systems, social cohesion, and agency" (Ziervogel et al., this issue).

Capacities also vary across scales, and the uneven distribution of capacity across scale leads to conflict and problems with definitions of sustainability and resilience. Development, adaptation, and lifestyle choices that benefit the powerful within a city often create costs for the less fortunate. At the heart of this conflict is the offloading, in time and space, of stressors and impacts to future generations and vulnerable populations and places. A political and economic spectrum of visibility is created within the SETEG, based on the dynamics of power, economics, space and time. Operating within this spectrum, urban actors may create an appearance of sustainability or resilience by offloading the effects of energy and water use, waste generation, and social and environmental disruptions and stressors in space and time (outside the visible spectrum). It is fundamental, therefore, to examine not only what urban sustainability and resilience mean, but for whom, where and when, sustainability and resilience will be operationalized.

For all its potential, community and city level engagement with urban sustainability and resilience is also faced with challenges. Some contributors to this issue explore the capacities with which urban actors have to interact, deliberate and collaborate to pursue diverse sustainability and resilience goals. Examples include co-developing master plans in Korneuburg, Austria; Fostering Communal Wellbeing in Bergrivier, South Africa; and Living Memorials Project in New York. Yet, no matter how promising these efforts are, they are also constrained by structural processes and dynamic pressures, such as sociodemographic shifts, enduring (or resilient) socio-spatial inequalities and the dynamics of power.

These processes and dynamic pressures are only beginning to be understood by a sustainability and resilience scholarship that has its roots in seventeenth century, empirical science. This science made possible the industrial revolution that unleashed our current environmental crises. It also led us, along relatively straight pathways, to the relationships urban areas have with the natural world. Creating sustainable and resilient urban relationships with the environment will entail a reimagining of those relationships. That reimagining will require that we improve our understanding of the dynamics of urban relationships with the environment across space and time. However, just as importantly, we must better understand our relationships with each other within and across domains of time, space, economics, and human organization.

Author Contributions: Patricia Romero-Lankao wrote the paper with substantial contributions of Daniel M., Gnatz. Olga Wilhelmi also contributed to the paper as did Mary Hayden.

Conflicts of Interest: The authors declare no conflict of interest. 


\section{References}

1. Jacobs, M. Fairness and Futurity: Essays on Environmental Sustainability and Social Justice; Oxford University Press: Oxford, UK, 2006; pp. 21-45.

2. Pelling, M. Adaptation to Climate Change: From Resilience to Transformation; Routledge: Abingdon-on-Thames, UK, 2010.

3. Berkes, F.; Folke, C.; Colding, J. Linking Social and Ecological Systems: Management Practices and Social Mechanisms for Building Resilience; Cambridge University Press: New York, NY, USA, 2000.

4. Turner, B. Vulnerability and resilience: Coalescing or paralleling approaches for sustainability science? Glob. Environ. Chang. 2010, 20, 570-576. [CrossRef]

5. Arup, RPA. Resilience-Sustainable Cities-Siemens. Available online: http://w3.siemens.com/ topics/global/en/sustainable-cities/resilience/Pages/home.aspx?stc=wwzcc120526 (accessed on 4 December 2014).

6. Selman, P. Local Agenda 21: Substance or spin? J. Environ. Plan. Manag. 1998, 41, 533-553. [CrossRef]

7. Zeemering, E.S. What does sustainability mean to city officials? Urban Aff. Rev. 2009, 45, 247-273. [CrossRef]

8. Grundmann, R. Climate change as a wicked social problem. Nat. Geosci. 2016, 9, 562-563. [CrossRef]

9. Bendor, R.; Anacleto, J.; Facey, D.; Fels, S.; Herron, T.; Maggs, D.; Peake, R.; Robinson, J.; Robinson, M.; Salter, J.; et al. Sustainability in an imaginary world. Interactions 2015, 22, 54-57. [CrossRef]

10. Maggs, D.; Robinson, J. Recalibrating the Anthropocene: Sustainability in an Imaginary World. Environ. Philos. 2016. [CrossRef]

11. Shove, E. Beyond the ABC: Climate change policy and theories of social change. Environ. Plan. A 2010, 42, 1273-1285. [CrossRef]

12. Galea, S.; Vlahov, D. Urban health: Evidence, challenges, and directions. Annu. Rev. Public Health 2005, 26, 341-365. [CrossRef] [PubMed]

13. Buhaug, H.; Urdal, H. An urbanization bomb? Population growth and social disorder in cities. Glob. Environ. Chang. 2013, 23, 1-10. [CrossRef]

14. Romero-Lankao, P.; Dodman, D. Cities in transition: Transforming urban centers from hotbeds of GHG emissions and vulnerability to seedbeds of sustainability and resilience: Introduction and Editorial overview. Curr. Opin. Environ. Sustain. 2011, 3, 113-120. [CrossRef]

15. Wirth, L. Urbanism as a Way of Life. Am. J. Sociol. 1938, 44, 1-24. [CrossRef]

16. Minx, J.; Baiocchi, G.; Wiedmann, T.; Barrett, J.; Creutzig, F.; Feng, K.; Förster, M.; Pichler, P.P.; Weisz, H.; Hubacek, K. Carbon footprints of cities and other human settlements in the UK. Environ. Res. Lett. 2013, 8, 035039. [CrossRef]

17. Seto, K.C.; Parnell, S.; Elmqvist, T. Urbanization, Biodiversity and Ecosystem Services: Challenges and Opportunities; Springer: Berlin, Germany, 2013; pp. 1-12.

18. Fujita, M. Urban Economic Theory: Land Use and City Size; Cambridge University Press: New York, NY, USA, 1989.

19. Logan, J.R.; Molotch, H.L.; Fainstein, S.; Campbell, S. The City as a Growth Machine. In The Gentrification Debates: A Reader; Routledge: Abingdon-on-Thames, UK, 1987.

20. Gallopín, G.C. Linkages between vulnerability, resilience, and adaptive capacity. Glob. Environ. Chang. 2006, 16, 293-303. [CrossRef]

21. Alberti, M.; Susskind, L. Managing urban sustainability: An introduction to the special issue. Environ. Impact Assess. Rev. 1996, 16, 213-221. [CrossRef]

22. Folke, C.; Hahn, T.; Olsson, P.; Norberg, J. Adaptive governance of social-ecological systems. Annu. Rev. Env. Resour. 2005, 30, 441-473. [CrossRef]

23. Ostrom, E.; Janssen, M.A.; Anderies, J.M. Going beyond panaceas. Proc. Natl. Acad. Sci. USA 2007, 104, 15176-15178. [CrossRef] [PubMed]

24. Romero-Lankao, P.; Gnatz, D.M. Conceptualizing Urban Water Security in an Urbanizing World. Curr. Opin. Environ. Sustain. 2016, 16. [CrossRef]

25. Vos, R.O. Defining sustainability: A conceptual orientation. J. Chem. Technol. Biotechnol. 2007, 82, $334-339$. [CrossRef]

26. Alberti, M. Measuring urban sustainability. Environ. Impact Assess. Rev. 1996, 16, 381-424. [CrossRef] 
27. Baumol, W.J.; Oates, W.E. Economics, Environmental Policy, and the Quality of Life; Gregg Revivals: Princeton NJ, USA, 1993.

28. Davidson, D.J. The applicability of the concept of resilience to social systems: Some sources of optimism and nagging doubts. Soc. Nat. Resour. 2010, 23, 1135-1149. [CrossRef]

29. Baumol, W.J.; Oates, W.E. The Theory of Environmental Policy; Cambridge University Press: New York, NY, USA, 1988.

30. Campbell, S.D. Sustainable development and social justice: Conflicting urgencies and the search for common ground in urban and regional planning. Mich. J. Sustain. 2013. [CrossRef]

31. Padilla, E. Intergenerational equity and sustainability. Ecol. Econ. 2002, 41, 69-83. [CrossRef]

32. Naess, A. The shallow and the deep, long-range ecology movement. A summary. Inquiry 1973, 16, 95-100. [CrossRef]

33. Fischer-Kowalski, M.; Swilling, M. Decoupling: Natural Resource Use and Environmental Impacts from Economic Growth; United Nations Environment Programme: Paris, France, 2011.

34. Daly, H.E.; Cobb, J.B.; Cobb, C.W. For the Common Good: Redirecting the Economy toward Community, the Environment, and a Sustainable Future; Beacon Press: Boston, MA, USA, 1994.

35. Gladwin, T.N.; Kennelly, J.J.; Krause, T.-S. Shifting paradigms for sustainable development: Implications for management theory and research. Acad. Manag. Rev. 1995, 20, 874-907.

36. Hart, S.L. Capitalism at the Crossroads: The Unlimited Business Opportunities in Solving the World's Most Difficult Problems; Pearson Education: New York, NY, USA, 2005.

37. Ikeme, J. Equity, environmental justice and sustainability: Incomplete approaches in climate change politics. Glob. Environ. Chang. 2003, 13, 195-206. [CrossRef]

38. Bulkeley, H.; Carmin, J.; Castán Broto, V.; Edwards, G.A.S.; Fuller, S. Climate justice and global cities: Mapping the emerging discourses. Glob. Environ. Chang. 2013, 23, 914-925. [CrossRef]

39. Hughes, S. Justice in Urban Climate Change Adaptation: Criteria and Application to Delhi. Ecol. Soc. 2013, 18, 48. [CrossRef]

40. Homsy, G.C.; Warner, M.E. Cities and sustainability polycentric action and multilevel governance. Urban Aff. Rev. 2015, 51, 46-73. [CrossRef]

41. Romero-Lankao, P.; Hardoy, J.; Hughes, S.; Rosas-Huerta, A.; Borquez, R.; Gnatz, D.M. 2015: Multilevel Governance and Institutional Capacity for Climate Change Responses in Latin American Cities. In The Urban Climate Challenge Rethinking the Role of Cities in the Global Climate Regime; Johnson, C., Toly, N., Schroeder, H., Eds.; Routledge: Abingdon-on-Thames, UK, 2015; pp. 179-204.

42. Betsill, M.M.; Bulkeley, H. Transnational networks and global environmental governance: The cities for climate protection program. Int. Stud. Q. 2004, 48, 471-493. [CrossRef]

43. Burch, S.; Schroeder, H.; Rayner, S.; Wilson, J. Novel multisector networks and entrepreneurship: The role of small businesses in the multilevel governance of climate change. Environ. Plan. C Gov. Policy 2013, 31, 822-840. [CrossRef]

44. Biermann, F.; Betsill, M.M.; Gupta, J.; Kanie, N.; Lebel, L.; Liverman, D.; Schroeder, H.; Siebenhüner, B.; Zondervan, R. Earth system governance: A research framework. Int. Environ. Agreem. Politics Law Econ. 2010, 10, 277-298. [CrossRef]

45. Gunderson, L.H. Panarchy: Understanding Transformations in Human and Natural Systems; Island Press: Washington, DC, USA, 2001.

46. Davoudi, S.; Shaw, K.; Haider, L.J.; Quinlan, A.E.; Peterson, G.D.; Wilkinson, C.; Fünfgeld, H.; McEvoy, D.; Porter, L.; Davoudi, S. Resilience: A Bridging Concept or a Dead End? "Reframing” Resilience: Challenges for Planning Theory and Practice Interacting Traps: Resilience Assessment of a Pasture Management System in Northern Afghanistan Urban Resilience: What Does it Mean in Planning Practice? Resilience as a Useful Concept for Climate Change Adaptation? The Politics of Resilience for Planning: A Cautionary Note. Plan. Theory Pract. 2012, 13, 299-333.

47. Ahern, J. From fail-safe to safe-to-fail: Sustainability and resilience in the new urban world. Landsc. Urban Plan. 2011, 100, 341-343. [CrossRef]

48. Carpenter, S.R.; Westley, F.; Turner, M.G. Surrogates for resilience of social-ecological systems. Ecosystems 2005, 8, 941-944. [CrossRef]

49. Adger, W.N. Social and ecological resilience: Are they related? Prog. Hum. Geogr. 2000, 24, 347-364. [CrossRef] 
50. Intergovernmental Panel on Climate Change. Climate Change 2014: Impacts, Adaptation, and Vulnerability. Part A: Global and Sectoral Aspects. Contribution of Working Group II to the Fifth Assessment Report of the Intergovernmental Panel on Climate Change; Field, C.B., Barros, V.R., Dokken, D.J., Mach, K.J., Mastrandrea, M.D., Bilir, T.E., Chatterjee, M., Ebi, K.L., Estrada, Y.O., Genova, R.C., et al., Eds.; Cambridge University Press: New York, NY, USA, 2014.

51. Folke, C.; Carpenter, S.; Elmqvist, T.; Gunderson, L.; Holling, C.S.; Walker, B. Resilience and sustainable development: Building adaptive capacity in a world of transformations. AMBIO J. Hum. Environ. 2002, 31, 437-440. [CrossRef]

52. Romero-Lankao, P.; Hughes, S.; Rosas-Huerta, A.; Borquez, R.; Gnatz, D. Urban Institutional Response Capacity for Climate Change: An examination of construction and pathways in Mexico City and Santiago. Environ. Plan. C 2013, 31, 785-805. [CrossRef]

53. Burch, S.; Robinson, J. A framework for explaining the links between capacity and action in response to global climate change. Clim. Policy 2007, 7, 304-316. [CrossRef]

54. Stirling, A. From Sustainability to Transformation: Dynamics and Diversity in Reflexive Governance of Vulnerability. 2014. Available online: https://papers.ssrn.com/sol3/papers.cfm?abstract_id=2742113 (accessed on 18 August 2016).

55. Romero-Lankao, P.; Gnatz, D.M. Exploring urban transformations in Latin America. Curr. Opin. Environ. Sustain. 2013, 5, 358-367. [CrossRef]

56. Geels, F.W.; Schot, J. Typology of sociotechnical transition pathways. Res. Policy 2007, 36, 399-417. [CrossRef]

57. Feola, G. Societal transformation in response to global environmental change: A review of emerging concepts. Ambio 2015, 44, 376-390. [CrossRef] [PubMed]

58. Moser, C.O.N. The asset vulnerability framework: Reassessing urban poverty reduction strategies. World Dev. 1998, 26, 1-19. [CrossRef]

59. Kollmair, M.; Gamper, S. The sustainable livelihoods approach. Available online: http://www.nccr-pakistan. org/publications_pdf/General/SLA_Gamper_Kollmair.pdf (accessed on 12 October 2016).

60. Brundtland, G.; Khalid, M.; Agnelli, S.; Al-Athel, S.; Chidzero, B.; Fadika, L.; Hauff, V.; Lang, I.; Shijun, M.; de Botero, M.M.; et al. Our Common Future (“Brundtland Report”). 1987. Available online: http:/ /www. citeulike.org/group/13799/article/13602458 (accessed on 19 September 2016).

61. Common, M.; Perrings, C. Towards an ecological economics of sustainability. Ecol. Econ. 1992, 6, 7-34. [CrossRef]

62. Hoel, M.; Sterner, T. Discounting and relative prices. Clim. Chang. 2007, 84, 265-280. [CrossRef]

63. Wackernagel, M.; Schulz, N.B.; Deumling, D.; Linares, A.C.; Jenkins, M.; Kapos, V.; Monfreda, C.; Loh, J.; Myers, N.; Norgaard, R.; et al. Tracking the ecological overshoot of the human economy. Proc. Natl. Acad. Sci. USA 2002, 99, 9266-9271. [CrossRef] [PubMed]

64. Campbell, S. Green cities, growing cities, just cities?: Urban planning and the contradictions of sustainable development. J. Am. Plann. Assoc. 1996, 62, 296-312. [CrossRef]

65. Holling, C.S. Understanding the complexity of economic, ecological, and social systems. Ecosystems 2001, 4, 390-405. [CrossRef]

66. Folke, C.; Carpenter, S.; Walker, B.; Scheffer, M.; Elmqvist, T.; Gunderson, L.; Holling, C.S. Regime shifts, resilience, and biodiversity in ecosystem management. Annu. Rev. Ecol. Evol. Syst. 2004, 35, 557-581. [CrossRef]

67. Gnatz, D.M. Climate Change Risks, Ecosystem Feedback, Vulnerability and Resilience in Urbanized Coastal Zones. 2015. Available online: http://nsuworks.nova.edu/cnso_stucap/168/ (accessed on 6 May 2016).

68. Gunderson, L.H.; Holling, C.S. Panarchy: Understanding transformations in Humans and Natural System; Island Press: Washington, DC, USA, 2002.

69. Pelling, M.; Manuel-Navarrete, D. From Resilience to Transformation: The Adaptive Cycle in Two Mexican Urban Centers. Ecol. Soc. 2011, 16, 11. Available online: http://www.ecologyandsociety.org/vol16/iss2/ art11/ (accessed on 22 April 2012). [CrossRef]

70. Norris, F.H.; Stevens, S.P.; Pfefferbaum, B.; Wyche, K.F.; Pfefferbaum, R.L. Community resilience as a metaphor, theory, set of capacities, and strategy for disaster readiness. Am. J. Community Psychol. 2008, 41, 127-150. [CrossRef] [PubMed] 
71. Tuckett, D.; Mandel, A.; Mangalagiu, D.; Abramson, A.; Hinkel, J.; Katsikopoulos, K.; Kirman, A.; Malleret, T.; Mozetic, I.; Ormerod, P.; et al. Uncertainty, decision science, and policy making: A manifesto for a research agenda. Crit. Rev. 2015, 27, 213-242. [CrossRef]

72. Saha, D.; Paterson, R.G. Local government efforts to promote the "Three Es" of sustainable development survey in medium to large cities in the United States. J. Plan. Educ. Res. 2008, 28, 21-37. [CrossRef]

73. Brandt, P.; Ernst, A.; Gralla, F.; Luederitz, C.; Lang, D.J.; Newig, J.; Reinert, F.; Abson, D.J.; von Wehrden, H. A review of transdisciplinary research in sustainability science. Ecol. Econ. 2013, 92, 1-15. [CrossRef]

74. Klenk, N.L.; Wyatt, S. The design and management of multi-stakeholder research networks to maximize knowledge mobilization and innovation opportunities in the forest sector. For. Policy Econ. 2015, 61, 77-86. [CrossRef]

75. Engle, N.L.; Lemos, M.C. Unpacking governance: Building adaptive capacity to climate change of river basins in Brazil. Glob. Environ. Chang. 2010, 20, 4-13. [CrossRef]

76. Tompkins, E.L.; Adger, W.N. Defining response capacity to enhance climate change policy. Environ. Sci. Policy 2005, 8, 562-571. [CrossRef]

77. Wilhelmi, O.V.; Hayden, M.H. Connecting people and place: A new framework for reducing urban vulnerability to extreme heat. Environ. Res. Lett. 2010, 5, 14-21. [CrossRef]

78. Romero-Lankao, P.; Hughes, S.; Qin, H.; Hardoy, J.; Rosas-Huerta, A.; Borquez, R.; Lampis, A. Scale, urban risk and adaptation capacity in neighborhoods of Latin American cities. Habitat Int. 2014, 42, 224-235. [CrossRef]

79. Romero-Lankao, P.; Gnatz, D.M.; Sperling, J. Examining Urban Inequality and Vulnerability to Enhance Resilience: Insights from Mumbai, India. Clim. Chang. 2016. [CrossRef]

80. Harlan, S.L.; Brazel, A.J.; Jenerette, G.D.; Jones, N.S.; Larsen, L.; Prashad, L.; Stefanov, W.L. In the shade of affluence: The inequitable distribution of the urban heat island. Res. Soc. Probl. Public Policy 2007, 15, 173-202.

81. Adger, W.N. Exploring income inequality in rural, coastal Viet Nam. J. Dev. Stud. 1999, 35, 96-119. [CrossRef]

82. United Nations Development Programme (UNDP). Sustainable Development Goals. Available online: http:/ / www.un.org/sustainabledevelopment/sustainable-development-goals/ (accessed on 9 May 2016).

83. Simon, D.; Arfvidsson, H.; Anand, G.; Bazaz, A.; Fenna, G.; Foster, K.; Jain, G.; Hansson, S.; Evans, L.M.; Moodley, N.; et al. Developing and testing the Urban Sustainable Development Goal's targets and indicators-A five-city study. Environ. Urban. 2016, 28, 49-63. [CrossRef]

84. Svara, J.H.; Watt, T.C.; Jang, H.S. How Are US Cities Doing Sustainability? Who Is Getting on the Sustainability Train, and Why? Cityscape 2013, 15, 9-44.

85. Blaikie, P.; Cannon, T.; Davis, I.; Wisner, B. At Risk: Natural Hazards, People's Vulnerability and Disasters; Routledge: London, UK, 2014.

86. Organisation for Economic Cooperation and Development (OECD). OECD Environmental Indicators: Development, Measurement and Use. Available online: http://www.oecd.org/environment/indicatorsmodelling-outlooks/24993546.pdf (accessed on 6 July 2016).

87. United Nations Environment Programme. Global Environment Outlook-5: Environment for the future we want. Available online: https://data.globalchange.gov/file/2446311f-e9ac-4c83-a7f8-07ca7122b09b (accessed on 16 May 2016).

88. Milman, A.; Short, A. Incorporating resilience into sustainability indicators: An example for the urban water sector. Glob. Environ. Chang. 2008, 18, 758-767. [CrossRef]

89. Piketty, T. Capital in the Twenty-First Century; Harvard University Press: Cambridge, MA, USA, 2014.

90. Garschagen, M.; Romero-Lankao, P. Exploring the relationships between urbanization trends and climate change vulnerability. Clim. Chang. 2015, 133, 37-52. [CrossRef]

91. Cutter, S.L.; Boruff, B.J.; Shirley, W.L. Social Vulnerability to Environmental Hazards. Soc. Sci. Q. 2003, 84, 242-261. [CrossRef]

92. Revi, A. Climate change risk: An adaptation and mitigation agenda for Indian cities. Environ. Urban. 2008, 20, 207-229. [CrossRef]

93. Vincent, K. Uncertainty in adaptive capacity and the importance of scale. Glob. Environ. Chang. 2007, 17, 12-24. [CrossRef]

94. Romero-Lankao, P.; Qin, H.; Dickinson, K. Urban vulnerability to temperature-related hazards: A meta-analysis and meta-knowledge approach. Glob. Environ. Chang. 2012, 22, 670-683. [CrossRef] 
95. Eakin, H.; Bojorquez-Tapia, L.A. Insights into the composition of household vulnerability from multicriteria decision analysis. Glob. Environ. Chang. 2008, 18, 112-127. [CrossRef]

96. Rashed, T.; Weeks, J. Assessing vulnerability to earthquake hazards through spatial multicriteria analysis of urban areas. Int. J. Geogr. Inf. Sci. 2003, 17, 547-576. [CrossRef]

97. Tah, J.; Carr, V. A proposal for construction project risk assessment using fuzzy logic. Constr. Manag. Econ. 2000, 18, 491-500. [CrossRef]

98. Giordani, P.; Giorgi, G. A fuzzy logic approach to poverty analysis based on the Gini and Bonferroni inequality indices. Stat. Methods Appl. 2010, 19, 587-607. [CrossRef]

99. Jepson, W. Measuring "no-win" waterscapes: Experience-based scales and classification approaches to assess household water security in colonias on the US-Mexico border. Geoforum 2014, 51, 107-120. [CrossRef]

100. O'Brien, K. Global environmental change II From adaptation to deliberate transformation. Prog. Hum. Geogr. 2012, 36, 667-676. [CrossRef]

101. Robinson, J.; Cole, R.J. Theoretical underpinnings of regenerative sustainability. Build. Res. Inf. 2015, 43, 133-143. [CrossRef]

102. Clark, W.C.; Crutzen, P.J.; Schellnhuber, H.J. Science for Global Sustainability: Toward a New Paradigm. 2005. Available online: https://papers.ssrn.com/sol3/papers.cfm?abstract_id=702501 (accessed on 17 September 2106).

103. Steffen, W.; Richardson, K.; Rockström, J.; Cornell, S.E.; Fetzer, I.; Bennett, E.M.; Biggs, R.; Carpenter, S.R.; de Vries, W.; de Wit, C.A.; et al. Planetary boundaries: Guiding human development on a changing planet. Science 2015, 347. [CrossRef] [PubMed]

104. Adger, W.N.; Lorenzoni, I.; O’Brien, K.L. Adapting to Climate Change: Thresholds, Values, Governance; Cambridge University Press: New York, NY, USA, 2009.

(C) 2016 by the authors; licensee MDPI, Basel, Switzerland. This article is an open access article distributed under the terms and conditions of the Creative Commons Attribution (CC-BY) license (http:/ / creativecommons.org/licenses/by/4.0/). 